\title{
TRADISI KEILMUAN PESANTREN SALAFI
}

\author{
M. Misbah \\ STAIN Purwokerto \\ Jl. A. Yani no. 40-A Telp (0281) 635624 Purwokerto 53126 \\ E-mail: misbahelya@yahoo.co.id \\ HP. +62-816689734
}

Abstract: This article reveals the tradition in Salafi Islamic boarding school as a unindegineous Islamic istitution in Indonesia. This institution applies Wahabi school, do a purification movement, al-raj'u ila al-Qur'an wa al-Sunah, and exclusivity. The Salafi tradition is grouped into four concepts of thought: Syari'at, Bid'ah, Khurafat and Tahayul. It is intended to straighten the Muslim way of thinking in order to be good Muslims. Meanwhile the knowledge traditions are: in Fiqh, the books that are discussed are:al-Wajiz written by Syeikh abdul Adhim al-Badawi, Mulakhash fiqh by Syekh Fauzan, Sifat Shalat Nabi by Syeikh al-Bani, kitab Bulughul Maram. They all refuse everything that has no rules in Islamic law and opposite to the Islamic believe. The Salafi-Wahabi knowledge tradition that is always emphasize to the text authority and limits the idea's role will cause the belief that al-Quran and hadis are perfect since they covers all life aspects of man. So, they made simplification that all religions that are not stated in al-Quran and hadis are believed as bid'ah. Meanwhile the doer is believed as a person who needs to be guidanced into the right way, by reminding or violence.

Abstrak: Artikel ini mengungkap tradisi keilmuan pesantren Salafi sebagai lembaga pesantren yang unindigenous Indonesia. Pesantren ini mempunyai misi mengusung faham salafi Wahabi; Melakukan gerakan Purifikasi (pemurnian/tashfiyyah tauhid), al-raj'u ila al-Qur'an wa al-Sunah, dan Ekslusifism. Tradisi pemikiran pesantren salafi dapat dikelompokkan pada empat hal, yakni; konsep pemikiran dalam hal Syari'at, Bid'ah, Khurafat dan Tahayul. Semua itu bertujuan dalam rangka meluruskan berbagai macam perilaku umat Islam yang menyimpang dari Syari'at yang murni. Di antara tradisi keilmuannya adalah; dalam bidang fikih, kitab yang dikaji adalah: al-Wajiz karya Syeikh Abdul Adhim al-Badawi, Mulakhash fiqh karya Syekh Fauzan, Sifat Shalat Nabi karya Syeikh al-Bani, kitab Bulughul Maram. Mereka menolak segala yang tidak ada at urannya dalam syari' at serta bertentangan dengan akidah Islam. Tradisi keilmuan salafi-Wahabi yang senantiasa menekankan pada otoritas teks dan membatasi peran akal 
akan mengakibatkan anggapan bahwa al-Qur'an dan Hadis bersifat sempurna karena telah mencakup seluruh aspek kehidupan manusia. Oleh karena itu, mereka kemudian melakukan simplikasi bahwa semua ajaran agama yang tidak tersurat dalam al-Qur'an dan Hadis dianggap sebagai bid'ah, sedangkan pelakunya dianggap sebagai orang yang perlu diluruskan, baik dengan peringatan at au dengan kekerasan.

Kata Kunci: Tradisi, pesantren, salafi, Wahabi, indegenous, unindigenous.

\section{A. Pendahuluan}

Akhir-akhir ini banyak pesantren yang tidak lagi merepresentasikan sebagai lembaga pendidikan indigenous Indonesia yang tetap menyandang ciriciri tradisionalnya, yang mengkaji kitab-kitab karya ulama masa lalu (kutub atturāts) yang biasa disebut dengan pesantren salafiyah (tradisional). Pesantren tersebut justru unindigenous Indonesia dan tidak tampak padanya ciri-ciri tradisionalnya. Begitu pula mereka tidak mengkaji kitab-kitab karya ulama masa lalu yang dikenal dengan istilah Kitab Kuning sebagaimana pesantren pada umumnya. Pesantren tersebut senantiasa mendengungkan untuk kembali kepada al-Qur'an dan al-Sunah (al raj'u ilā al-Qur'ān wa al-Sunnah) dalam segala sendi kehidupan yang meliputi ibadah, sosial, budaya dan lain sebagainya.

Pesantren yang unindigenous Indonesia tersebut kemudian menamakan dirinya sebagai Pesantren "Salafi" yang justru mengaku sebagai pembela alQur'an dan al-Sunah Nabi SAW dari berbagai praktik keagamaan dan kehidupan yang menyimpang. Penamaan pesantren "Salafi" inilah yang kemudian menjadi satu hal yang membingungkan kaum awam ketika dihadapkan dengan Pesantren "Salaf/Salafiyah" yang tradisional tersebut. Pesantren salafi tradisional senantiasa memelihara dan mempertahankan budaya dan tradisi ke-Indonesiaan, mengakomodir budaya lokal, lebih mengedepankan kemaslahatan secara umum (al-mașlahat al-'ammat), toleransi dan tidak mudah menyalahkan (membid'ahkan, mengkafirkan) orang lain. Adapun di sisi lain, pesantren atau golongan salafi yang satunya dengan dalih memperjuangkan dan membela Islam, mereka berusaha keras menolak budaya dan tradisi yang selama ini telah menjadi bagian integral kehidupan bangsa ini, mereka ingin menggantinya dengan budaya dan tradisi asing dari Timur Tengah, terutama kebiasaan WahabiIkhwanul Muslimin. Mereka selalu bersikap keras dan tidak kenal kompromi terhadap kelompok yang tidak sefaham, mudah menyalahkan (membid'ahkan, mengkafirkan) pihak lain, dan dalam hal tradisi keilmuan mereka sangat tekstualis (dari kebiasaan-kebiasaan tersebut mereka kemudian dikenal sebagai 
kelompok "garis keras"). Klaim-klaim implisit para aktivisnya mengaku telah memahami maksud kitab suci sepenuhnya dan karena itu mereka berhak menjadi wakil Allah (khalifat Allah) dan menguasai dunia ini dengan memaksa siapapun mengikuti pemahaman 'sempurna' mereka. Klaim ini tidak dapat diterima secara teologis maupun politis (El Fadl, 2003: 48).

Berdasarkan gambaran tersebut, tulisan ini mengungkap tentang tradisi keilmuan yang ada pada pesantren Salafi (pesantren yang unindigenous Indonesia). Agar eksistensinya dapat dipertahankan, maka seorang Kiai mempunyai peran yang sangat sentral. Keberadaanya dalam lingkungan sebuah pesantren ibarat jantung bagi kehidupan manusia. Selain itu, tradisi keilmuan yang ada juga harus senantiasa diajarkan dengan konsep-konsep dan aplikasi yang mendalam.

\section{B. Terminologi Salafi}

Kata Salafi adalah sebuah bentuk penisbatan kepada al-Salaf. Kata al-Salaf sendiri secara etimologis bermakna orang-orang yang mendahului atau hidup sebelum zaman kita (كلّ من تقدّمك من آبائك ), nenek moyang yang lebih tua dan lebih dahulu. Salaf berarti para pendahulu (Munawwir, 1997: 651). Jika dikatakan "salafu al-rajuli"= salaf seseorang, maksudnya kedua orang tua yang telah mendahuluinya. Adapun makna al-Salaf secara terminologis berarti generasi pertama dan terbaik dari ummat (Islam) ini. Yang dimaksud di sini adalah generasi yang dibatasi oleh sebuah penjelasan Rasulullah SAW dalam haditsnya (Al Maktabah al Syamilah):

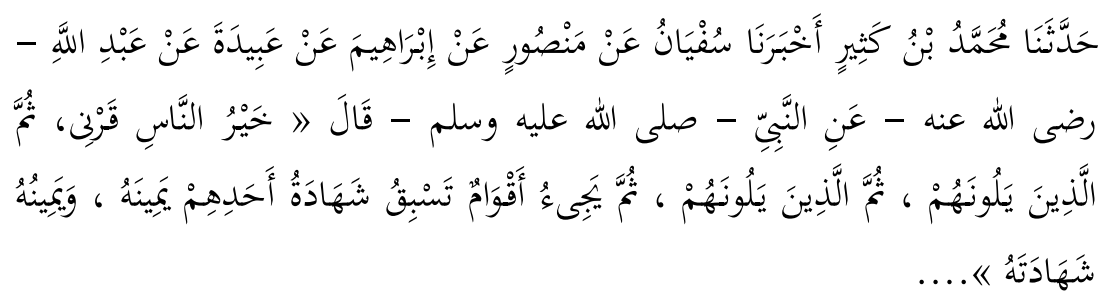

"Sebaik-baik manusia adalah (yang hidup) di masaku, kemudian yang mengikuti mereka, kemudian yang mengikuti mereka....." (HR. Bukhari).

Berdasarkan hadits ini, maka yang dimaksud dengan al-Salaf adalah para sahabat Nabi SAW, kemudian tạbi 'ỉn, lalu atba' tābi'īn dan para Imam pembawa petunjuk pada tiga kurun (generasi/masa) pertama yang dimuliakan oleh Allah SWT. Karena itu, ketiga kurun ini kemudian dikenal juga dengan sebutan alQurun al-Mufaḍḍalah (kurun-kurun yang mendapatkan keutamaan) (AlThalibi, 2006). Salafi merupakan perujukan kepada pergerakan yang telah lama 
mapan dalam Islam yang bert ujuan menempa keyakinan keagamaan berpijak pada teladan generasi pertama pengikut Nabi Muhammad SAW.

Sebagian ulama kemudian menambahkan label al-Ṣālih (menjadi al-Salaf al-Șālih) untuk memberikan karakter pembeda dengan pendahulu kita yang lain. Seorang salafi berarti seorang yang mengaku mengikuti jalan para sahabat Nabi SAW, al-tābi'in dan atba' al-tābi'inn dan para imam pembawa petunjuk pada tiga kurun pertama dalam seluruh sisi ajaran dan pemahaman mereka. Dari penjelasan tersebut, dapat diketahui bahwa ideologi salafi pada hakikatnya bukanlah satu hal yang perlu diperdebatkan, karena pada dasarnya setiap muslim akan mengakui legalitas kedudukan para sahabat Nabi SAW dan generasi terbaik umat Islam sesudahnya itu; al-tābi'inn dan atba' al-tābi'īn. Oleh karena itu, setiap muslim baik sebagai individu maupun dalam organisasi tertentu ketika mengikuti jalan para sahabat Nabi SAW, al-tābi'inn dan atba' altābi'in dan mengikuti jalan para imam pembawa petunjuk pada tiga kurun pertama baik menyatakan secara langsung ataupun tidak maka mereka disebut sebagai pengikut al-salaf al-ṣālih.

Penggunaan istilah Salafi ini secara khusus tertuju pada kelompok gerakan Islam tertentu setelah maraknya apa yang disebut "Kebangkitan Islam di Abad 15 Hijriyah". Terutama yang berkembang di Tanah Air, mereka memiliki beberapa ide dan karakter yang khas yang kemudian membedakannya dengan gerakan pembaruan Islam lainnya. Kelompok gerakan Islam yang termasuk dalam kelompok salafi/salafiyah ini adalah sebagian pengikut Imam Ahmad yang muncul pada abad $4 \mathrm{H}$, kemudian pada abad $7 \mathrm{H}$ muncul Ibnu Taimiyah yang berusaha membela dan menyebarkannya serta para pengikut Wahabi (Muhammad bin Abdul Wahhab pada abad $12 \mathrm{H}$ ).

Kaum Wahabi dan Ibn Abdul Wahhab sendiri menyatakan bahwa pemikiran mereka berasal dari kelompok Salafiyah seperti yang dikembangkan oleh Ibn Taimiyah. Pemikiran Salafiyah inilah, yang menurut mereka merupakan pemikiran yang mengikuti metode salaf shaleh dari kalangan Sahabat, Tabi'in, Atba' Tabi'in, yang selalu mengikuti Sunah Nabi SAW. (Wahyudi (Ed.), 2009: 9-10). Hal ini juga diungkapkan oleh Muhammad Abu Zahrah, dalam Tārikh al-Maz̄āhib al-Islāmiyyah: fi al-Siyāsah wa al-'Aqā'id, (Tt. : 211). Salafi meyakini bahwa wajib memberikan nama golongan yang selamat ini sebagai salafi dan melarang golongan lain menggunakan nama tersebut. Jadi penisbatan kepada salaf adalah sebuah keniscayaan, sehingga jelaslah bagi salafi (pengikut salaf) terhadap al-haq (Wardi (Ed.), 2007: 18). Dari paparan tersebut, dapat ditekankan bahwa yang dimaksud kelompok Salafi di sini adalah kelompok yang 
mengikuti Muhammad bin Abdul Wahhab (kelompok Wahabi) sebagai imamnya dengan segala manhaj dan karakteristiknya yang berbeda dengan gerakan pembaharuan Islam pada umumnya.

\section{Karakteristik Pesantren Salafi}

Secara historis, pesantren tidak hanya mengandung makna keislaman tetapi juga mengandung makna indigenous (keaslian) Indonesia. Tentang prinsip indigenousity pesantren ini, Azyumardi Azra menulis:

"Sebagai lembaga pendidikan indigenous, pesantren memiliki akar sosiohistoris yang cukup kuat, sehingga membuatnya mampu menduduki posisi yang relatif sentral dalam dunia keilmuan masyarakatnya, sekaligus bertahan dalam berbagai gelombang perubahan. Kalau kita menerima spekulasi bahwa "pesantren" telah ada sebelum masa Islam, maka boleh jadi ia merupakan satu-sat unya lembaga pendidikan dan keilmuan di luar istana. Jika ini benar, berarti pesantren merupakan semacam lembaga counter culture (budaya tandingan) terhadap budaya keilmuan yang dimonopoli kalangan istana dan elite Brahmana (Azra, 1999: 87).

Pesantren merupakan hasil dari penyerapan akulturasi kebudayaan HinduBudha dan kebudayaan Islam yang kemudian menjelma menjadi suatu lembaga yang kita kenal sebagai pesantren sekarang ini. Pondok pesantren secara definitif tidak dapat diberikan batasan yang tegas melainkan terkandung fleksibilitas pengertian yang memenuhi ciri-ciri yang memberikan pengertian pondok pesantren. Pondok pesantren belum ada pengertian yang lebih konkret karena masih meliputi beberapa unsur untuk dapat mengartikan pondok pesantren secara komprehensif.

Dari berbagai macam pengertian tentang pesantren yang dapat dikaji (Azizy, 2000: 102, Mastuhu, 1994: 55, Wahid, 1999: 14, Arifin, 1991: 240), dapat diketahui bahwa pesantren adalah suatu lembaga pendidikan dan pengajaran agama Islam yang mempunyai ciri-ciri tertentu dan juga merupakan sistem pendidikan yang mengandung makna keaslian (indigenous) Indonesia dan tertua yang berkembang di tengah-tengah masyarakat Indonesia dengan sasaran utama yaitu tafaqquh fī al-dīn (mendalami agama) sebagai pedoman kehidupan sehari-hari. Pesantren adalah bentuk pesantren yang tetap memelihara dan mempertahankan budaya dan tradisi ke-Indonesiaan, mengakomodir budaya lokal, lebih mengedepankan kemaslahatan secara umum (al-maṣlahat al'āmmat), toleransi dan tidak mudah menyalahkan (mem-bid'ahkan, mengkafirkan, memusyrikkan) orang lain. Pesantren inilah yang menyandang pesantren salafiyah model "NU" (Sufi) dan moderat. 
Pesantren salafi adalah pesantren yang menganut faham Wahabi, yang mengikuti pemikiran mereka yang berasal dari kelompok Salafiyah seperti yang dikembangkan oleh Ibn Taimiyah (Meskipun dalam beberapa hal, antara salafiyah Ibnu Taimiyah dengan salafiyah Wahabi itu ada perbedaan, di antaranya: kelompok salafiyah Ibnu Taimiyah memiliki pemikiran kalam (teologi Islam) sendiri dan berdebat dengan lawan-lawannya, dakwah secara persuasif, memandang yang harus sesuai dengan aturan tekstual al-Qur'an dan Sunah adalah hanya masalah ibadah. Salafiyah Wahabi mengharamkan menggunakan pemikiran kalam, kalau perlu dakwah dengan pedang dan kekerasan, memperluas yang harus sesuai dengan al-Qur'an dan Sunah tidak hanya masalah ibadah saja tetapi lebih luas lagi termasuk adat kebiasaan masyarakat (Wahyudi (Ed.) 2009: 9-17). Adapun karakteristik Pesantren Salafi adalah sebagai berikut.

\section{Melakukan Gerakan Purifikasi (Pemurnian Tauhid)}

Sejalan dengan pandangan Ibn Abdil Wahhab (yang memandang bahwa banyak praktik kaum muslimin yang mengandung bid'ah, khurafat dan kemusyrikan (syirk), yang bertentangan dengan ajaran tauhid di kalangan umat Islam saat ini) maka pesantren salafi pun berusaha untuk melakukan pemurnian tauhid. Gerakan pemurnian tauhid ini tidak hanya dalam hal akidah saja, tetapi dalam bidang fikih, tafsir, hadis maupun sejarah juga dalam rangka purifikasi. Apakah dalam praktik keilmuan tersebut terdapat unsur bid'ah atau tidak.

Tauhid menurut mereka pada dasarnya adalah pengabdian (ibadah) hanya kepada Allah dengan cara yang benar-benar mengesakan-Nya. Tauhid dalam pandangan mereka dibagi menjadi tiga. Pertama, tawhìd rubübiyyah/the tawhid of lordship, yang berkenaan dengan pengesaan Allah sebagai Maha Pencipta segala sesuatu yang terlepas dari segala macam pengaruh dan sebab, yang menghidupkan dan mematikan (refers to God's possession of absolute power over Heaven and Earth, life and death). Kedua, tawhịd asmā wa șifät/the tawhid of characteristics yang berhubungan dengan pengesaan nama dan sifat-sifat Allah yang berbeda dengan makhluk-Nya. (that is, God's characteristics are defined by God's role as Lord and Divine Being). Ketiga, Tawhìd Ilāhiyah/the tawhid of divinity, yang berkaitan dengan pengesaan Allah sebagai Tuhan Yang Disembah (requires devotion to service and worship of God alone by all creation) (Delong - Bas, 2004: 56-57).

Tawhīi Ilāhiyah, yang intinya adalah pengesaan dalam beribadah hanya kepada Allah akan terwujud setidaknya apabila terpenuhi dua hal: 
a. Hanya menyembah Allah semata-mata dan tidak mengakui sifat ketuhanan bagi selain Allah. Barang siapa yang mengikutsertakan makhluk untuk disembah bersama-sama Allah berarti ia telah melakukan kemusyrikan (thus anyone who serves or worships anyone or anything else, even the righteous Ancestors (salihin) or angels, has departed from Islam. Muslims are to recognize God alone as the ruler of universe and without equal) (Delong Bas, 2004: 57).

b. Dalam menyembah dan beribadah kepada Allah harus sesuai dengan cara yang telah disyari'atkan oleh Allah melalui Nabi SAW.

Konsekuensi dari dua hal tersebut adalah:

1) Tidak boleh mengangkat manusia, baik hidup atau sudah meninggal untuk dijadikan perantara (wasìlah) dengan maksud mendekatkan diri kepada Allah.

2) Tidak boleh ziarah ke makam-makam orang saleh dan para nabi untuk meminta do'a, juga tidak boleh mensakralkan semua itu (termasuk dalam hal yang dilarang adalah Tawassul, Tabarruk, Ziarah Kubur, Karamah Wali karena semua itu termasuk dalam kategori syirik Ilāhiyyah. Orang yang melakukannya dihukumi musyrik, bagi yang tidak bertaubat dianggap kafir dan boleh dibunuh. Hal inilah yang kemudian memunculkan banyak reaksi dari para ulama termasuk Syeikh Ja'far Subḥani yang menulis buku "Wahabiyah fi Al-Mizān”, yang diterjemahkan menjadi Tawassul, Tabarruk, Ziarah Kubur, Karamah Wali Termasuk Ajaran Islam (Kritik Atas Faham Wahabi), Zahir (pentj.) 1989).

Oleh karena itu, perbuatan yang menyimpang dan bertentangan dengan pengesaan Allah dalam beribadah ini merupakan perbuatan bid'ah dalam beragama dan kemusyrikan. Dalam menyebarkan ajaran ini, kelompok salafi wahabi ini dengan menggunakan kekuatan bahkan kekerasan, karena cara-cara persuasif itu dianggap tidak efektif.

\section{Al-Raj'u Ilā al-Qur'ān wa al-Sunnah}

Dalam hal pemahaman akan aqidah, fiqh, dan lain sebagainya mereka senantiasa berslogan "kembali" pada Qur'an dan Sunah. Mereka merujuk langsung kepada para sahabat yang hidup pada masa Nabi SAW, para tabi'in, tanpa harus melewati para ulama empat madzhab. Pesantren salafi-wahabi membatasi bahwa "kembali" kepada al-Qur' an dan Sunah berarti memahami sumber tersebut secara tekstualis, rigid, anti Barat, skripturalis tidak boleh ada penafsiran lain. Apabila ada interpretasi terhadap teks, maka dianggap batal, dan bid'ah. 


\section{Terlihat Ekslusif}

Pondok pesantren Salafi-Wahabi senantiasa mengajarkan kepada seluruh santrinya untuk meniru semua hal yang ada dalam syari' at secara tekstual, seperti cara berpakaian, berpenampilan dan berperilaku, yang meniru cara berpakaian, berpenampilan dan berperilaku orang Arab (Wahyudi (Ed.), 2009: 219-220). Mereka sama sekali tidak membenarkan berpakaian model orang Indonesia (Jawa), berpenampilan dan berperilaku sebagaimana asal orang tersebut. Hal ini sebagai konsekuensi dari ideologi mereka yang menyatakan bahwa generasi yang terbaik adalah generasi sahabat, tābi'in dan atba' al-tābi'inn. mereka berpendapat bahwa umat Islam harus mengikutinya dalam segala amal ibadah, akidah serta adat istiadat mereka.

Dari paparan tersebut dapat diketahui bahwa karakter mereka secara umum adalah: merasa dirinya paling benar dan satu-sat unya golongan yang selamat, benar dan masuk surga; golongan yang lain adalah sesat dan bid'ah serta lebih berbahaya daripada golongan fasik; hanya mereka yang berhak menyandang nama salafi, suka mencela golongan/ulama lain; golongan sesat dan bid'ah harus dihambat gerakannya dan kalau perlu dimusnahkan (di antaranya dengan cara hajr al-mubtadi' (Wardi (Ed.), 2007: 167-185).

Dengan ajaran pesantren Salafi-Wahabi yang seperti itu, maka kelompok Salafi-Wahabi juga dikenal dengan kelompok yang beraliran keras "garis keras" atau kelompok fundamentalis, revivalis, skripturalis, tekstualis, ușūliyyūn, islāmiyyūn, aṣliyyūn, salafiyyun dan muta'așib. Hal inilah yang kemudian mendasari Ed Husain untuk menuliskan pengalamannya ketika menjadi pengikut Hizb al-Tahrir di London. Apa yang menjadi ketertarikannya terhadap kelompok tersebut sehingga ia bergabung di dalamnya serta apa yang menjadikan ketidaktertarikan serta kekecewaannya sehingga ia keluar dari kelompok tersebut (Ed Husain, 2007: 83-110). Azra mengatakan bahwa, kelompok Islam tekstualis dan fundamentalis memiliki beberapa karakter di antaranya adalah:

a. Fundamentalisme adalah oppositionalism (paham perlawanan). Fundamentalisme dalam agama manapun mengambil bentuk perlawanan yang tidak jarang bersifat radikal terhadap segala ancaman yang dipandang membahayakan eksistensi agama. Ancaman tersebut dapat berupa modernitas atau modernisme, sekularisasi dan tata nilai Barat pada umumnya.

b. Fundamentalisme identik dengan penolakan terhadap hermeneutika. Mereka menolak terhadap sikap kritis terhadap teks dan interpretasinya. Teks al-Qur'an harus dipahami secara literal. 
c. Fundamentalisme merupakan penolakan terhadap pluralisme dan relativisme. Mereka memandang pluralisme merupakan hasil yang keliru terhadap teks kitab suci (Coward, 1997).

d. Fundamentalisme menolak terhadap perkembangan historis dan sosiologis. Mereka memandang bahwa perkembangan sosiologis dan historis telah membawa manusia semakin jauh dari doktrin literal teks Kitab Suci. Oleh karena itu, masyarakatlah yang harus menyesuaikan perkembangannya (kalau perlu dengan kekerasan) dengan teks Kitab Suci, bukan sebalikya (Azra, 1996: 109110, Wahyudi (Ed.), 2009: 59-63).

Itulah beberapa karakteristik pesantren Salafi-Wahabi. Karakteristiknya tidak dapat terlepas dari karakteristik aliran Salafi-Wahabi itu sendiri sehingga pesantren-pesantren salafi juga terkenal dengan pesantren-pesantren fundamentalis, literalis, ushuliyyun, dan lain sebagainya.

\section{Tradisi Keilmuan Pesantren Salafi}

Sebagaimana telah diketahui bahwa di antara gerakan yang sampai saat ini masih eksis di dunia Islam dan masih aktif dalam menyebarkan misinya adalah gerakan Wahabi. Tidak dapat dipungkiri bahwa gerakan Salafi di Indonesia banyak dipengaruhi oleh ide dan gerakan pembaruan yang dilancarkan oleh Muhammad ibn 'Abd al-Wahhab di kawasan Jazirah Arabia. Ide pembaruan Ibn 'Abd al-Wahhab diduga pertama kali dibawa masuk ke kawasan Nusantara oleh beberapa ulama asal Sumatera Barat pada awal abad ke-19. Inilah gerakan Salafiyah pertama di tanah air yang kemudian lebih dikenal dengan gerakan kaum Padri, yang salah satu tokoh utamanya adalah Tuanku Imam Bonjol dan Haji Miskin. Gerakan ini sendiri berlangsung dalam kurun waktu $1803 \mathrm{M}$ hingga sekitar $1832 \mathrm{M}$ (http://abusalafy.wordpress.com/2007/07/30/gerakansalafi-modern-di-indonesia/).

Khusus di Indonesia, pengaruh Wahabi awalnya terbagi dalam empat gelombang. Pertama, gelombang yang melahirkan perang Padri yang dimotori oleh Haji Miskin, Haji Sumanik, Haji Piabang bersama dengan Tuanku Nan Renceh (1821 M-1837 M) di Sumatera Barat. Kedua, Pemberontakan Banten (1888) yang terinspirasi Pan Islamisme. Ketiga, berdirinya organisasi massa berbasis Pan Islam dan Purifikasi seperti Syarikat Islam (SI) (1905 M), Muhammadiyah (1912 M), Al-Irsyad (1914 M), dan Persatuan Islam (1923 M). Keempat, terwujud dalam gerakan DI/TII. Baru kemudian, di akhir abad 20, muncul gelombang kelima pengaruh Wahabi dalam bentuk munculnya gerakan Salafi yang pada dekade 90-an membentuk lembaga pesantren Salafi Wahabi yang puritan fundamentalis (meskipun menurut Abdul Munir Mulkhan bahwa 
Gerakan Fundamentalisme di pedesaan telah memudar karena adanya resistensi masyarakat petani terhadapnya. Para petani lebih memilih pada apa yang disebut "Neo-Sufiisme" (Mulkan, 2000).

Berdasarkan penelitian yang sudah pernah dilakukan tentang Pesantren pengikut Wahabi (Wahyudi, 2009: 131-279, Abdullah, dkk. 2008, Azra, 2000: 11-13), maka dapat diketahui tentang tradisi keilmuan Pesantren Salafi yang tidak berbeda dengan pemikiran salafi-wahabi pada umumnya. Tradisi pemikiran pesantren salafi dapat dikelompokkan pada empat hal, yakni; konsep pemikiran dalam hal Syari'at, Bid'ah, Khurafat dan Tahayul. Semua itu bertujuan dalam rangka meluruskan berbagai macam perilaku umat Islam yang menyimpang dari Syari'at yang murni.

Selanjutnya, tradisi pemikiran pesantren salafi Wahabi tersebut dapat dipaparkan sebagai berikut:

1. Tradisi pemikiran dalam hal Syari'at (yang mereka pahami sebagai fikih) bersifat lengkap dan mutlak kebenarannya, sehingga tidak memerlukan lagi interpretasi dan kontekstualisasi. Syari' at Islam sudah mutlak kebenarannya, sehingga tugas manusia hanyalah melaksanakan Syari' at tanpa reserve karena manusia adalah hamba Allah di muka bumi. Sebagaimana dalam QS. Al-Jatsiyat: 18. Oleh karena itu, yang benar adalah syari' at yang tertuang dalam al-Qur' an dan al-Hadis Nabi SAW secara tekstual. Adapun interpretasi manusia merupakan pelanggaran terhadap kebenaran syari' at karena masuk dalam kategori perbuatan yang mengikuti hawa nafsu. Dengan demikian, segala hal yang berkaitan dengan kehidupan umat Islam niscaya harus dikembalikan kepada al-Qur'an dan Sunah dengan tidak perlu memperhatikan konteks yang mengitari turunnya ayat al-Qur'an (asbāb al-nuzūl) dan munculnya hadis (asbāb al-wurūd).

2. Bid'ah, adalah segala sesuatu yang tidak diajarkan oleh Nabi SAW dalam persoalan ibadah, seperti ziarah kubur yang ditentukan waktunya (setiap malam Jum'at), Tahlilan yang ditentukan wakt unya serta dipakai sebagai wasīlah (perantara), manāqib-an untuk menghormati seorang tokoh spiritual dan dziba'an. Apabila pengamalan semua itu karena pengaruh budaya dan tradisi nenek moyang yang dianggap sebagai sebuah kebenaran bukan karena beribadah kepada Allah maka kegiatan tersebut dianggap sebagai bid'ah.

3. Takhayul, adalah ajaran yang dipercayai keberadaannya oleh masyarakat tetapi pada dasarnya ajaran tersebut tidak ada dan bertentangan dengan akidah Islam. Seperti kepercayaan masyarakat Yogyakarta terhadap keberadaan Ratu Kidul. Hal tersebut kemudian menimbulkan satu kepercayaan bagi 
masyarakat untuk mengadakan ritual tertentu. Apabila kepercayaan itu secara total maka perbuatan tersebut dianggap syirik.

4. Khurafāt, di antara bentuknya adalah melakukan ziarah kubur dengan tujuan meminta kepada orang yang sudah meninggal dan dilaksanakan setiap malam Jum'at. Begitu pula dengan perbuatan tahlilan, ini dianggap sebagai bid'ah dan khurafat karena tidak pernah dilakukan oleh Nabi Muhamad SAW dalam konteks diperuntukkan bagi arwah yang telah meninggal dunia. Selain itu juga tidak pernah dipraktikkan oleh para sahabat, serta tidak disebutkan dalam al-Qur'an maupun Hadis.

Tradisi pemikiran tersebut pada dasarnya dalam rangka menuju terwujudnya pengamalan ajaran Islam yang murni. Kekokohan mereka dalam menyebarkan akidahnya menjadikan mereka merasa yang paling berhak menjadi wakil Allah di muka bumi ini. Hal ini patut disadari karena posisi etis yang menganggap bahwa kehidupan yang baik terwujud dalam ketaatan terhadap tolok-ukur keyakinan dan perilaku yang bersifat intuitif dan / atau diwahyukan, pada umumnya menerima jalur penalaran yang dapat diikhtisarkan menjadi lima titik dasar sebagai berikut:

1. Ada jawaban-jawaban otoritatif terhadap seluruh problema kehidupan yang memiliki arti penting.

2. Jawaban-jawaban itu pada dasarnya bersandar pada kewenangan dari luar (eksternal); entah itu dalam wahyu keagamaan yang diterima para nabi dan orang-orang suci yang didukung oleh iman atau akal sehat.

3. Jawaban-jawaban itu bukan saja otoritatif melainkan juga sederhana dan langsung pada titik permaslahan. Mereka tidak mengandung makna ganda, tidak mendua, bisa langsung dimengerti, tidak membutuhkan tafsiran khusus ataupun campur tangan pakar. Jawaban-jawaban itu apa adanya dan merupakan kebenaran ḥarfiyah.

4. Jawaban-jawaban yang disediakan oleh intuisi/iman sudah cukup bagi siapapun yang berhasrat untuk hidup secara baik.

5. Untuk kehidupan yang baik, betapapun orang tidak hanya perlu kembali ke kepastian-kepastian kebijaksanaan umum, atau ke agama yang sederhana dan langsung ke pokok masalah. Tetapi perlu juga untuk memurnikan masyarakat kontemporer, melenyapkan unsur-unsur yang tidak perlu dan mengalihkan perhatian yang membuat orang tidak bisa memusatkan secara jernih pada kebutuhan hidup mendasar sebagaimana seharusnya. Oleh karena itu perlu kembali ke cara-cara lama yang lebih baik dan sudah teruji kebenarannya (O' Neil, 2001: 187-190). 
Dalam rangka mempertahankan sekaligus menyebarkan tradisi pemikiran salafi terhadap para santri dalam pesantren tersebut, maka pesantren salafi juga mempunyai tradisi keilmuan yang berbeda dengan tradisi keilmuan pada pondok pesantren lainnya (yang bukan salafi wahabi). Di antara tradisi keilmuannya adalah:

1. Dalam bidang fikih, kitab yang dikaji adalah: al-Wajiz karya Syeikh abdul Adhim al-Badawi, Mulakhaș Fiqh karya Syekh Fauzan, Sifat Șalāt Nabī karya Syeikh al-Bani, kitab Bulūghul Marām.

2. Dalam Bidang Hadis: Hadis an-Nawawi karya Imam An-Nawawi

3. Dalam bidang akidah, Ușūl al-Tsalatsah karya Ibn Abdul Wahab.

Tradisi pengkajian kitab-kitab tersebut hanyalah dikaji sebatas maknanya saja, kemudian dipercayai secara mendalam sehingga mereka menganggap bahwa norma-norma yang ada dalam kitab-kitab tersebut sebagai kebenaran mutlak. Akibat dari kepercayaan tersebut adalah cara berpakaian dan perilaku mereka yang disesuaikan dengan apa yang, menurut mereka, terdapat dalam al-Qur'an, Hadis, dan kitab-kitab yang dipahami secara tekstual. Cara berpakaian dan berperilaku mereka semakin ekstrem karena mereka kurang bisa membedakan antara kitab fikih, hadis, dan tafsir. Semua kitab yang mereka kaji dianggap sebagai syari' at yang benar dan harus diikuti. Akibatnya mereka menolak segala yang tidak ada at urannya dalam syari' at serta bertentangan dengan akidah Islam (Wahyudi, 2009: 188).

\section{E. Kritik atas Tradisi Keilmuan Salafi Wahabi}

Apabila dilihat dari corak transmisi ilmu pengetahuan dari Timur Tengah ke Indonesia khususnya, sebetulnya ada dua corak dan metode yang mewarnai para transmitter (sejumlah murid Jawi) utama tradisi intelektual keagamaan tradisi Islam dari pusat-pusat keilmuan Islam di Timur Tengah tersebut. Kecenderungan intelektual-keagamaan yang paling mencolok yang muncul dari jaringan ulama adalah harmonisasi antara syari'at dan tasawuf. Tasawuf dalam konteks ini telah diperbaharui sehingga menjadi lebih sesuai dengan tuntutan syari'at yang sering disebut dengan istilah "neo-sufism". Rekonsiliasi dan harmonisasi antara syariat dan tasawuf telah ditekankan sejak masa lebih awal oleh tokoh semacam al-Ghazali, tetapi rekonsiliasi itu mencapai momentumnya terutama melalui jaringan para ulama.

Fathi Osman sebagaimana dikutip oleh Bahtiar Effendy mengatakan:

"To say that Islam deals with the spiritual life, with no interference in society and the state, may be as far from reality as saying that Islam provides a 
comprehensive and detailed social, economic and political system. The law of Islam, shari'a, in its two divine sources -the Qur'an and the Sunah, the verbal and practical traditions of the prophet-is permanent, but its direct legal rules and limited; at the same time, the intellectual derivatives (as represented in the voluminous jurisprudential works) and the accumulated practical behavior of Muslim societies during successive centuries in different places (as represented in historical records) are changeable and extensive. Both parts are sometimes mixed and confused, not only in the view of some non-Muslim observers and scholars, but also in the view of some enthusiastic Islamic propagators" (Effendi, 2003: 1).

Meskipun kebanyakan ulama dalam jaringan mempunyai komitmen kepada pembaruan Islam, namun tidak terdapat keseragaman di antara mereka dalam hal metode dan pendekatan untuk mencapai tujuan ini. Kebanyakan mereka memilih pendekatan damai dan evolusioner, tetapi sebagian kecil, di antaranya yang terkenal adalah Ibn Abdul Wahhab, lebih memilih pendekatan dan cara-cara radikal dan perang. Hal ini sesuai dengan apa yang dikatakan oleh Ibn Taimiyah yang dikutip oleh Ahmad Baso: "Agama yang benar hanya akan tegak dengan Kitab Petunjuk dan Kekuatan Pedang Penolong” (kāna qiwām aldìn bi al-muṣhạ wa al-saif, fainna qiwām al-dìn bi al-kitāb al-hādi wal-ḥadid alnāṣir), (Baso, 2006: 164-165), serta menekankan agar umat Islam senantiasa menegakkan Syari'at (sesuai dengan perspektif mereka) (Siddiqui, 2002).

Hal inilah yang kemudian menjadikan agama sering tampil dalam dua wajah yang saling bertentangan, di satu sisi wajah yang santun, damai, saling menghormati sehingga menjadi tempat orang menemukan kedamaian, kedalaman hidup dan harapan yang kukuh. Di sisi wajah yang lainnya adalah wajah peperangan, arogansi, tidak ramah (Haryatmoko, 2004: 62).

Tampilan wajah yang tidak ramah, arogansi, sikap yang radikalis, fundamentalis dalam beragama merupakan konsekuensi dari Tradisi intelektual pesantren Salafi tersebut. Bagi mereka, agama merupakan suatu ekspresi dari at uran yang suci yang secara skematik berlawanan dengan at uran sekuler. Dalam perspektif ini, aturan Tuhan mengganti aturan manusia (Tibi, 1998: 20). Hal itu dimaksudkan dalam rangka purifikasi at as berbagai kegiatan keagamaan yang dianggap telah melenceng dari syari'ah. Begitu juga dalam pemahaman teks al-Qur'an dan hadis (syari' ah) secara tekstualis, literalis menjadikan mereka menut up semua jalan yang menyebabkan adanya penafsiran/interpretasi lain selain teks tersebut. Merekapun tidak mencoba meneliti lebih jauh tentang teks yang dibaca karena dianggap hanya akan menuruti hawa nafsu belaka. Konsekuensinya terhadap hasil istinbāt al-hukmi al-Islāmi menjadikan hukum yang 
kaku, rigid, tidak fleksibel serta tidak sesuai dengan kemaslahatan masyarakat, karena epistimologi yang dipakai adalah bayani (metode pemikiran yang menekankan otoritas teks (nash) dan dijustifikasi oleh naluri penarikan kesimpulan) (Al-Jabiri, 1991, 1990).

Kemaslahat an masyarakat merupakan landasan pokok dari suatu hukum yang diwahyukan (maqāṣid al-sỵari'a), karenanya ahli hukum harus mempertimbangkan kemaslahatan masyarakat ini dalam mengembangkan hukum. Tujuan ditetapkannya syari' ah adalah untuk melindungi agama, kehidupan, keturunan, akal dan harta (Auda, 2008).

Gus Dur berpandangan bahwa Islam sebenarnya berintikan tiga prinsip; musāwah (prinsip persamaan), 'ādalah (prinsip keadilan), dan syūrā (prinsip musyawarah/demokrasi). Segala kegiatan dalam kehidupan bermasyarakat maupun dalam aktivitas keagamaan mestilah bersendikan ketiga prinsip ini yang diramu sedemikian rupa sehingga sesuai dengan kenyataan dan kebutuhan yang dihadapi. Gus Dur melihat Islam dan pluralisme itu dalam konteks manifestasi universalisme dan kosmopolitanisme dalam Islam. Menurutnya, ajaran yang dengan sempurna menampilkan kosmopolitanisme Islam adalah lima jaminan dasar (al-kulliyah al-khamsa) atas umat manusia; jaminan dasar atas keselamatan keyakinan, keselamatan fisik, kesucian keluarga, harta milik, dan jaminan atas keselamatan profesi (Anwar, 1995: 233).

Sikap dan sifat toleransi dan moderasi yang Nabi SAW ajarkan harus senantiasa menjadi acuan dan pedoman dalam interaksi dengan umat agama lain yang notabene keberadaan mereka yang berbeda adalah sunnatullāh. Oleh karena itu, ketika terhadap umat lain saja harus mengedepankan sifat toleransi dan moderasi apalagi terhadap sesama umat Islam sendiri. Dengan demikian, akan tercipta masyarakat Muslim yang mempunyai akhlak yang mulia baik terhadap sesama muslim sendiri maupun terhadap yang lainnya serta akan menampilkan agama dengan tampilan wajah yang rahmat li al-'alamin.

Tradisi keilmuan salafi-Wahabi yang senantiasa menekankan pada otoritas teks akan mengakibatkan anggapan bahwa al-Qur' an dan Hadis bersifat sempurna karena telah mencakup seluruh aspek kehidupan manusia. Anggapan ini kemudian melahirkan sikap membatasi ijtihad (yang mereka nyatakan terbuka dan mutlak harus dilakukan dengan alasan tidak ada larangan dari Nabi SAW) untuk menjaga kemurnian ajaran agama yang bersifat sakral. Pola pemahaman seperti ini menjadikan fikih mandul (tidak adaptif terhadap perubahan zaman dan perkembangan peradaban) karena dianggap final, lengkap dan mutlak kebenarannya. Fikih, yang mestinya hanyalah interpretasi ulama atas teks keagamaan terkait dengan persoalan yang mereka hadapi dianggap sebagai 
kebenaran mutlak. Akibatnya, banyak sekali problem kontemporer yang tidak bisa dijawab oleh fikih.

Menurut Moosa (termasuk intelektual lain yang seirama dengan pemikirannya tentang Islam adalah Esack (1977: 2-8), beberapa upaya untuk memperkenalkan kompleksitas di dalam memahami al-Qur'an adalah permulaan untuk menghilangkan penutup kemasabodohan kita. Al-Qur'an sebagai sebuah teks adalah hidup di dalam komunitas Muslim kontemporer dan menjadi subjek dari berbagai dimensi kehidupannya (al-Qur'an șalị̣ likulli zamān wa makān).

Pada masa lalu, al-Qur'an memiliki konteks di mana dalam konteks ini, alQur'an dinegosiasikan dengan agenda masyarakat yang bermacam-macam sebagaimana ketika pertama diwahyukan. Moosa ingin mengatakan bahwa alQur'an memiliki semacam “sejarah Politik". Dengan istilah ini, menurutnya, alQur'an muncul dalam rangka melawan kemerosotan kekuasaan dan sejarah. Kehadiran al-Qur'an adalah membangun sejarah yang baru dan beragama sebagaimana mewujud di dalam masyarakatnya. Oleh karena itu, kita perlu mengetahui tidak hanya konteks sosial yang rinci di mana al-Qur'an dimainkan di dalam sejarah, akan tetapi juga bagaimana al-Qur'an bermain di dalamnya. Apabila kita mengkaji sejarah masyarakat al-Qur' an yang berbeda-beda tanpa melihat keterlibatan manusia di teks-teks kitab suci, maka kita akan kesulitan untuk memahami wahyu dan komunitasnya yang bermacam-macam.

Apabila kita menengok corak gerakan pemikiran (keilmuan) mereka, akan terlihat adanya kelesuan intelektual ketika berbicara tentang pemikiran Islam. hal ini tidak lain karena jargon kembali kepada al-Qur'an dan al-Sunah melahirkan dua arah yang berbeda. Pertama, pola pikir atau nalar yang bersifat skripturalistik sebagai konsekuensi logis dari sikap mengembalikan rujukan wacana secara langsung kepada al-Qur'an (muṣhaf) dan al-Sunah, karena tanpa dilengkapi kerangka metode dan pendekatan yang baru dan kreatif. Mereka terpaku dengan kreasi pemikir modernis yang mengilhami mereka, dengan mengabaikan realitas di mana para pemikir itu hidup. Kedua, pola pikir atau nalar yang liberal, tentu jika disertai dengan perumusan kembali metode dan pendekatan yang baru dan kreatif. Tetapi yang kedua ini justru tidak mendapat respon dari kalangan mereka (Wijaya, 2011: 119-120).

Tradisi keilmuan Salafi-Wahabi (termasuk Pesantren Salafi Wahabi) sangat membatasi peran akal untuk menanyakan atau mengkritisi teks. Padahal Islam sangat menghargai rasio dan ilmu pengetahuan. Karena dengan ilmu pengetahuanlah manusia dapat menterjemahkan ayat-ayat Tuhan, baik ayat qawliyyah maupun kawniyyah. Teks keagamaan tidak akan bermanfaat apa-apa bagi manusia jika mereka tidak mau menggunakan akal pikiran mereka untuk 
menterjemahkannya ke dalam realitas yang mereka hadapi (Wahyudi, 2009: 189-190).

Dikarenakan kurang dapat memfungsikan akal secara proporsional, mereka terjebak dalam penafsiran para Sahabat dan tabi'in, yang dalam banyak hal sudah tidak kontekstual dengan era kontemporer. Oleh karena itu, mereka kemudian melakukan simplikasi bahwa semua ajaran agama yang tidak tersurat dalam al-Qur'an dan Hadis dianggap sebagai bid'ah, sedangkan pelakunya dianggap sebagai orang yang perlu diluruskan baik dengan peringat an atau dengan kekerasan.

\section{F. Simpulan}

Tradisi pemikiran pesantren salafi dapat dikelompokkan pada empat hal, yakni; konsep pemikiran dalam hal Syari'at, Bid'ah, Khurafat dan Tahayul. Semua itu bertujuan dalam rangka meluruskan berbagai macam perilaku umat Islam yang menyimpang dari Syari' at yang murni. Semua kitab yang mereka kaji dianggap sebagai syari' at yang benar dan harus diikuti. Akibatnya mereka menolak segala yang tidak ada aturannya dalam syari'at serta bertentangan dengan akidah Islam. Tradisi keilmuan Salafi-Wahabi (termasuk Pesantren Salafi Wahabi) sangat membatasi peran akal untuk menanyakan atau mengkritisi teks. Padahal Islam sangat menghargai rasio dan ilmu pengetahuan. Karena dengan ilmu pengetahuanlah manusia dapat menterjemahkan ayat-ayat Tuhan, baik ayat qawliyyah maupun kawniyyah. Mereka kemudian melakukan simplikasi bahwa semua ajaran agama yang tidak tersurat dalam al-Qur'an dan Hadis dianggap sebagai bid'ah, sedangkan pelakunya dianggap sebagai orang yang perlu diluruskan baik dengan peringatan atau dengan kekerasan.

\section{Daftar Pustaka}

Al-Jabiri, Muhammad Abed. 1991. Naqd al-'Aql al-'Araby 1: Takwin al-'Aq1 al-'Araby. Beirut: al-Markaz al-Tsaqafy al-'Araby, cet. IV.

Al-Thalibi, Abu Abdirrahman. 2006. Dakwah Salafiyah Dakwah Bijak, Meluruskan Sikap Keras Dai Salafi. Jakarta: Hujjah Press.

Anwar, M. Syafi'i. 1995. Pemikiran dan Aksi Islam Indonesia. Jakarta: Paramadina.

Arifin, H.M. 1991. Kapita Selekta Pendidikan: Islam dan Umum. Jakarta: Bumi Aksara. 
Auda, Jasser. 2008. Maqasid al-Shariah as Philosophy of Islamic Law; a Systems Approach. London-Washington: The International Institute of Islamic Thought.

Baso, Ahmad. 2006. NU Studies; Pergolakan Pemikiran Antara Fundamentalisme Islam dan Fundamentalisme Neo-Liberal. Jakarta: Erlangga.

Coward, Harold. 1997. Setting The Research for Canadian Religions Pluralism, ARC 25.

Delong - Bas, Nataja J. 2004. Wahabi Islam; From Revival and Reform to Global Jihad. New York: Oxford University Press.

Dhofier, Zamakhsyari. 1982. Tradisi Pesantren (Studi Tentang Pandangan Hidup Kyai). Jakarta: LP3ES.

Ed Husain, 2007. The Islamist; Why I Joined Radical Islam in Britain, What I Saw Inside and Why I Left. London: Penguin Books.

El Fadl, Khaled Abou. 2003. Atas Nama tuhan: dari Fikih Otoriter ke Fikih Otoritatif, diterjemahkan dari Speaking in God's Name: Islamic Law, Authority And Women. Jakarta: Serambi Ilmu Semesta.

Esack, Farid. 1997. Qur'an, Liberation \& Pluralism: an Islamic Perspectives of Interreligious Solidarity Against Oppression. England: Oneworld.

Haryatmoko, 2004. Etika Politik dan Kekuasaan. Jakarta: Kompas.

Idahram, Syaikh. 2011. Sejarah Berdarah Sekte Salafi Wahabi; Mereka Membunuh Semuanya Termasuk Para Ulama, Cet. XII. Yogyakarta: Pustaka Pesantren.

Madjid, Nurcholish. 1985. Merumuskan Kembali Tujuan Pendidikan Islam dalam Dawam Rahardjo (Ed.), Pergulatan Dunia Pesantren, Membangun dari Bawah. Jakarta: P3M.

Mastuhu. 1994. Dinamika Sistem Pendidikan Pesantren. Jakarta: INIS.

Moosa, Ebrahim. 2004. Islam Progresif: Refleksi Dilematis tentang HAM, Modernitas dan Hak-Hak Perempuan di dalam hukum Islam, Terj. Yasrul Huda, Syafiq Hasyim (Ed.), Jakarta: ICIP.

Mulkhan, Abdul Munir. 2000. Neo-Sufisme dan Pudarnya Fundamentalisme di Pedesaan, Yogyakarta: UII Press.

Munawwir, Ahmad Warson. 1997. Kamus Al-Munawwir. Surabaya: Pustaka Progressif.

O’ Neil, William F. 2001. Ideologi-ideologi Pendidikan, pengantar Mansour Fakih. Yogyakarta: Pustaka Pelajar. 
Ruslani. 2000. Masyarakat Kitab dan dialog Antar Agama (Studi Atas Pemikiran Mohammed Arkoun). Yogyakarta: Yayasan Bentang Budaya.

Shihab, Alwi. 2005 "Menyikapi Pluralisme Agama", dalam Opini Republika tanggal 9 Agustus 2005.

Shihab, Quraish. 2000. Tafsir Al-Misbah, jilid 2. Ciputat Jakarta: Lentera Hati. Siddiqui, Kalim. 2002. Seruan-Seruan Islam; Tanggung Jawab Sosial dan Kewajiban Menegakkan Syari'at, Akhmad Affandi dan Humaidi (pent.). Yogyakarta: Pustaka Pelajar.

Subhani, Syeikh Ja'far. 1989. "Wahabiyah fi Al-Mizan”, yang diterjemahkan menjadi Tawassul, Tabarruk, Ziarah Kubur, Karamah Wali Termasuk Ajaran Islam (Kritik Atas Faham Wahabi), Zahir (pentj.). Jakarta: Pustaka Hidayah.

Tibi, Bassam. 1998. The Challenge of Fundamentalism; Political Islam and The New world Disorder. London, England: University of California Press.

Wahid, Abdurrahman. 1999. Membangun Demokrasi, Bandung: Remaja Rosda-karya.

Wahyudi, K. Yudian (Ed.) 2009. Gerakan Wahabi di Indonesia (Dialog dan Kritik). Yogyakarta: Pesantren Nawesea Press.

Wardi, Zahro (Ed.). 2007. Polaritas Sektarian; Rekonstruksi Doktrin Pinggiran. Kediri: Tinta.

Yasmadi. 2002. Modernisasi Pesantren (Kritik Nurcholis Madjid Terhadap Pendidikan Islam Tradisional). Jakarta: Ciputat Press.

Zahrah, Muhammad Abu. TT. Tarikh al-Mazahib al-Islamiyyah: fi al-Siyasah wa al-'Aqaid. Ttp.: Dar al-Fikr al-'Arabi. 